\title{
Lupus-related protein-losing enteropathy associated with pseudo-pseudo Meigs' syndrome and successfully treated with hydroxychloroquine
}

\author{
TARO HORINO ${ }^{1}$, MASAMI OGASAWARA ${ }^{1}$, TAKESHI KASHIO ${ }^{1}$, SATOSHI INOTANI ${ }^{1}$, MASAYUKI $^{2}$ \\ ISHIHARA ${ }^{2}$, HIROSHI OHNISHI ${ }^{3}$, MASAHIRO KOMORI $^{4}$, OSAMU ICHII $^{5}$, YOSHIO TERADA ${ }^{1}$
}

\author{
${ }^{1}$ Department of Endocrinology, Metabolism and Nephrology, Kochi Medical School, Kochi University, Kohasu, Oko-cho, Nankoku, \\ Kochi 783-8505, Japan \\ ${ }^{2}$ Department of Pediatrics, Kochi Medical School, Kochi University, Kohasu, Oko-cho, Nankoku, Kochi 783-8505, Japan \\ ${ }^{3}$ Department of Hematology and Respiratory Medicine, Kochi Medical School, Kochi University, \\ Kohasu, Oko-cho, Nankoku, Kochi 783-8505, Japan \\ ${ }^{4}$ Department of Otolaryngology, Kochi Medical School, Kochi University, Kohasu, Oko-cho, Nankoku, Kochi 783-8505, Japan \\ ${ }^{5}$ Laboratory of Anatomy, Department of Basic Veterinary Sciences, Faculty of Veterinary Medicine, Hokkaido University, Kita 18, \\ Nishi 9, Kita-Ku, Sapporo 060-0818, Japan
}

\begin{abstract}
We herein report the first case of lupus-related protein-losing enteropathy associated with pseudopseudo Meigs' syndrome. Lupus-related protein-losing enteropathy and pseudo-pseudo Meigs' syndrome are extremely rare complications in patients with systemic lupus erythematosus, Both have a similar clinical course characterized by producing marked ascites, and respond to steroids in typical cases. However, in our case, steroid monotherapy was inadequate and the addition of hydroxychloroquine was effective for their treatment. Furthermore, no reports have previously confirmed elevated CA 125 levels with lupus-related protein-losing enteropathy or increased 99mTc-HSA activity with pseudo-pseudo Meigs' syndrome. In addition, we are the first to report an evaluation of the histopathology of lupus-related proteinlosing enteropathy. Previously reported cases have been described as being caused by either pseudoMeigs's syndrome or lupus-related protein-losing enteropathy as the cause of the rare pathology that causes marked pleural effusion and ascites in patients with systemic lupus erythematosus, but it has not been evaluated whether the other is co-occurring. Our case highlights that there is a potential case of overlapping lupus-related protein-losing enteropathy and pseudo-Pseudo-Meigs's syndrome. Furthermore, it is possible that patients with marked ascites with elevated CA 125 levels were mistakenly diagnosed with Meigs's syndrome or pseudo-Meigs's syndrome associated with malignant or benign ovarian tumors and underwent surgery. Clinicians should not forget SLE with pseudo-Pseudo-Meigs's syndrome as one of the differential diagnoses for marked ascites with elevated CA 125 levels.
\end{abstract}

Key words: cancer antigen 125, lupus-related protein-losing enteropathy, pseudo-PseudoMeigs's syndrome, technetium-99m-labeled human serum albumin scintigraphy.

\section{INTRODUCTION}

Systemic lupus erythematosus (SLE) causes multiple organ disorders and is a common autoimmune disease, especially in women [1]. Protein-losing enteropathy (PLE) can occur as an idiopathic disorder but can also be a manifestation of various diseases, including SLE. PLE associated with SLE is called lupus-related PLE (LUPLE) [2]. Pseudo-pseudo Meigs' syndrome, first described by Tjalma in 2005 [3], is a newly emerging SLE manifestation, characterized by pleural effusion, ascites, and elevated cancer antigen 125 (CA 125). Both LUPLE and pseudo-pseudo Meigs' syndrome are rare complications in SLE patients. Furthermore, the coexistence of both diseases has not been reported in the English literature so far. Herein, we report a case of LUPLE associated with pseudo-pseudo Meigs' syndrome.

\section{CASE REPORT}

A 53-year-old woman presented with a massive pleural effusion, ascites, polyarthralgia, and erythema of the extremities. She had developed massive ascites 2 years prior and, given a high CA 125 level (763 [normal: <35] U/mL), underwent a total hysterectomy and right oophorectomy for suspected ovarian cancer or Meigs' syndrome. However, histopathological analysis showed no malignancy. She was then transferred for palliative care for suspected cancer of an unknown primary 
site because the ascites did not improve postoperatively. After 4-month dexamethasone (DEX) therapy (dose unknown), her ascites improved, her CA 125 level was $16.0 \mathrm{U} / \mathrm{mL}$, and she was discharged.

However, ascites recurred 1 month prior to admission; physical examination revealed massive ascites, generalized oedema, polyarthralgia of the fingers, and erythema of the extremities. Laboratory examinations revealed a reduced albumin level (0.8 [normal: $4.1-5.1] \mathrm{g} / \mathrm{dL}$ ) and elevated C-reactive protein ( 0.63 [normal: $<0.15$ ] $\mathrm{mg} / \mathrm{dL})$ and serum amyloid A (SAA) (14.6 [normal: <8.0] $\mu \mathrm{g} / \mathrm{mL}$ ) levels. Her total cholesterol and low-density lipoprotein levels were 512 (normal: 142-248) and 408 (normal: $65-163$ ) $\mathrm{mg} / \mathrm{dL}$, respectively. The total complement (CH50), $\mathrm{C} 3$, and $\mathrm{C} 4$ levels decreased to 26.1 (normal: 31.6-57.6) U/mL, 49.7 (normal: 73-138) mg/dL, and 9.1 (normal: $11-31$ ) $\mathrm{mg} / \mathrm{dL}$, respectively. Serology was positive for speckled antinuclear (160x, normal: <40x), anti-RNP (38.4 [normal: <3.5] U/mL), anti-Sm (40.0 [normal: <7.0] U/mL), and SSA (237.7 [normal: <7] U/mL) antibodies. Her white blood cell count was $4600 / \mu \mathrm{L}$ and lymphocyte count was $1330 / \mu \mathrm{L}$. Urinalysis results were normal. Her CA 125 level was 767.5 U/mL. Chest and abdominal computed tomography scans revealed massive pleural effusion and ascites (Figure 1A, 1B). Cytology of the pleural effusion and ascites fluids showed no malignancy. A 72-hour $\alpha 1$-antitrypsin stool clearance study showed a clearance of 310 (normal: <31) mL/day. Scintigraphy showed technetium-99m-labeled human serum albumin ( $\left.{ }^{99 \mathrm{~m}} \mathrm{Tc}-\mathrm{HSA}\right)$ in the stomach one hour after injection (Figure 2A, 2B) and in the duodenum after three hours (Figure 2C). Upper gastrointestinal endoscopy revealed mild gastritis without mucosal disruption (Figure 2D) and no remarkable findings of the duodenum, with a biopsy specimen showing mild non-specific submucosal inflammatory cell infiltration (Figure 2E) and granular deposition of $\operatorname{Ig} \mathrm{A}$ and $\operatorname{IgM}$ in the stromal area (Figure 2F). A colonoscopy showed unremarkable findings. Based on the diagnostic criteria for SLE $[1,4,5]$, she was diagnosed with SLE because of polyarthralgia, erythema, pleural effusion, lymphopenia, positive antinuclear antibodies, positive anti-Sm antibodies, and hypocomplementemia. Furthermore, according to the above findings, the association of pseudo-pseudo Meigs' syndrome and LUPLE caused by SLE was diagnosed.

Figure 3 shows the clinical course of this case. Intravenous methylprednisolone (mPSL) (1 g/day) was administered for 3 days, followed by 3 days' oral prednisolone (PSL) (40 mg/day) and another 3 days of mPSL, with inadequate effect. Intravenous cyclophosphamide $(500 \mathrm{mg} / \mathrm{day})$ was administered for 5 days without improvement. Hydroxychloroquine (HCQ) (200 mg/day) was added with 5 days' intravenous immunoglobulin ( $20 \mathrm{~g} /$ day). Finally, PSL ( $25 \mathrm{mg} /$ day) was switched to DEX (4 mg/day), and her symptoms, including the pleural effusion and ascites (Figure 1C, 1D), and laboratory test results improved. DEX was tapered to $1.5 \mathrm{mg} /$ day in the outpatient clinic. No relapses were reported during the 1-year follow-up.

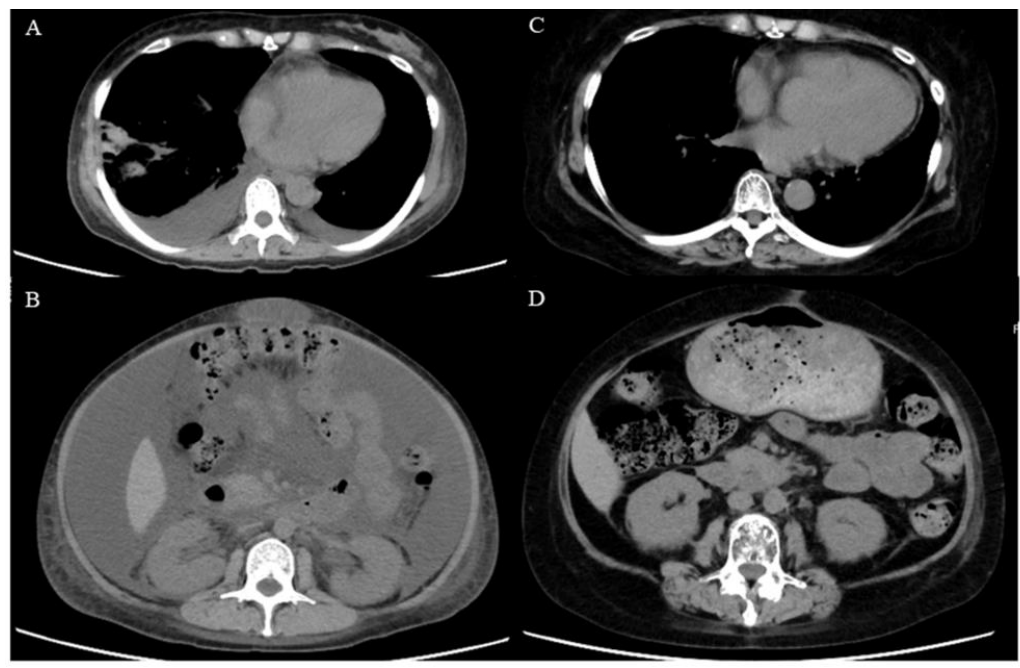

Figure 1. Computed tomography of the chest and abdomen

A) Computed tomography (CT) of the chest on admission revealing pleural effusion

B) CT of the abdomen on admission revealing ascites

C) $\mathrm{CT}$ of the chest after 9 months showing no pleural effusion

D) CT of the abdomen after 9 months showing no ascites. 


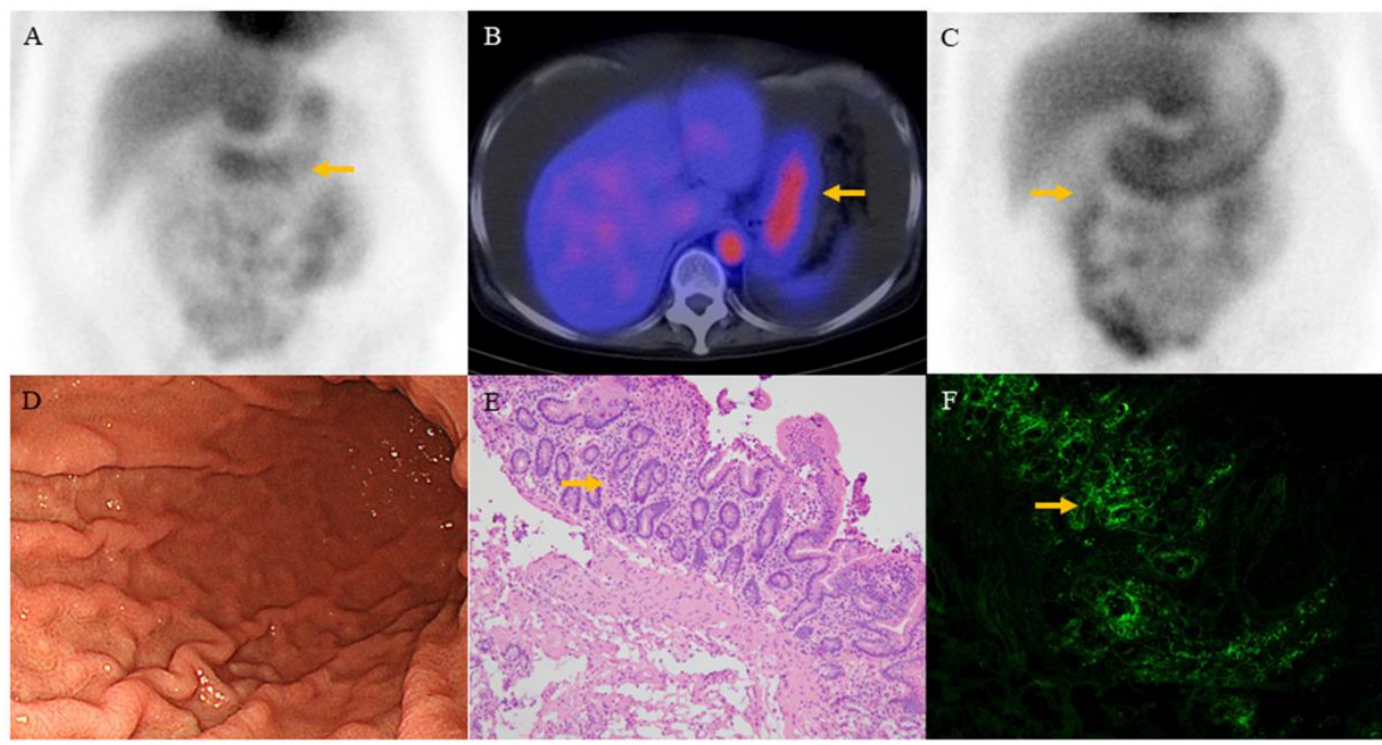

Figure 2. Technetium-99m-labeled human serum albumin (99mTc-HSA) scintigraphy and upper endoscopy A, B) $99 \mathrm{mTc}-\mathrm{HSA}$ scintigraphy showing $99 \mathrm{mTc}-\mathrm{HSA}$ in the stomach 1 hour after injection (arrows)

C) $99 \mathrm{mTc}-\mathrm{HSA}$ scintigraphy showing $99 \mathrm{mTc}-\mathrm{HSA}$ in the duodenum 3 hour after injection (arrow) D) Upper endoscopy revealing mild gastritis without mucosal disruption

E) The histopathological findings of the biopsy specimen of the duodenum revealing atrophic mucosa, oedematous change to the lamina propria and submucosa with dilated capillaries and lymphatic duct, and mild to moderate lymphocyte-dominant inflammatory cell infiltration in the lamina propria (arrow) (periodic acid-Schiff stain)

F) Immunofluorescent findings of the biopsy specimen of the duodenum revealing fine granular deposition of $\operatorname{IgA}$ in the stromal area between the crypt basement membrane and the crypt base.

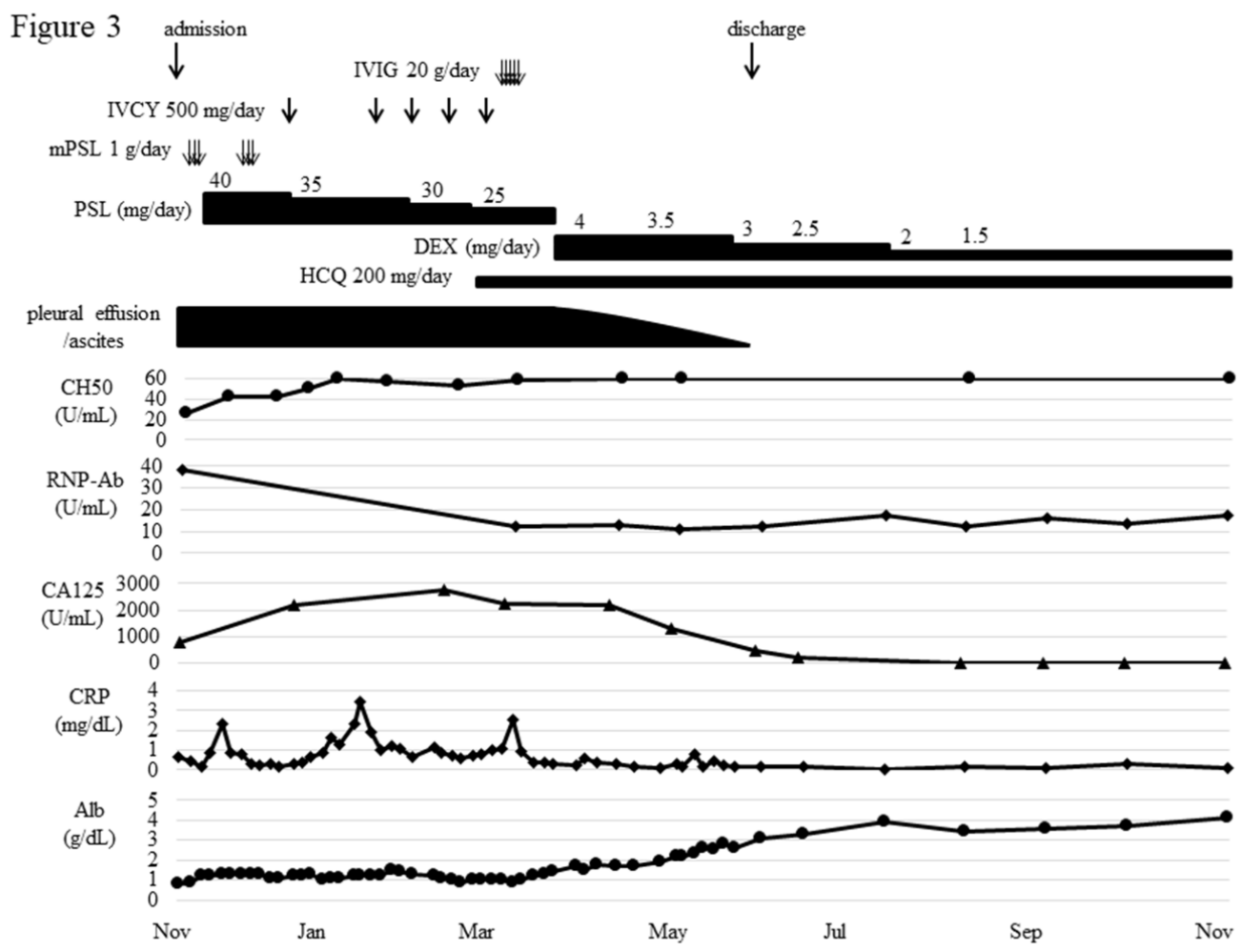

Figure 3. Clinical course of our case.

IVCY; intravenous cyclophosphamide, IVIG; intravenous immunoglobulin, PSL; prednisolone, DEX; dexamethasone, HCQ; hydroxychloroquine, mPSL; methyl prednisolone, RNP-Ab; anti-RNP antibodies, CA-125; cancer antigen 125, CRP; C-reactive protein, Alb; albumin 


\section{DISCUSSION}

PLE involves serum protein loss from the gastrointestinal tract, followed by hypoproteinaemia, pleural effusion, and ascites [2]. Because early-stage PLE is relatively asymptomatic, and LUPLE is uncommon in SLE patients, it is frequently missed [6]. LUPLE almost exclusively affects women and is characterized by hypercholesterolaemia [7, 8]. Furthermore, LUPLE is accompanied by hypocomplementemia and positive autoantibodies (e.g. dsDNA, anti-RNP, anti-Sm), with levels normalizing as the disease symptoms improve [6]. The autoimmune inflammatory response may be the most likely mechanism of LUPLE [6]. So far, no reports have been made on the histopathological findings of LUPLE. In our case, histological examination revealed immune deposits in the gastric mucosal tissue, suggesting that the immune response may be involved in the pathogenesis of protein leakage.

Pseudo-pseudo Meigs' syndrome presents with clinical features similar to Meigs' syndrome and pseudo-Meigs' syndrome, including pleural effusion, ascites, and a high CA 125 level, and is easily misdiagnosed. While Meigs' syndrome and pseudo-Meigs' syndrome are secondary to benign ovarian fibromas or other abdominal or pelvic malignancies and resolve after tumour removal, pseudo-pseudo Meigs' syndrome occurs in SLE patients without abdominal or pelvic tumours [9]. The pathophysiology of underlying ascites in pseudo-pseudo Meigs' syndrome is debated. CA 125 levels mirror the disease activity and decrease with disease resolution [10]. CA 125 is a commonly used tumour marker, but lacks sensitivity and specificity for ovarian malignancies; its levels can be elevated in other conditions (e.g. SLE) [9]. In inflammatory conditions, CA 125 secretion is increased from the mesovarium and omentum [11]. CA 125 levels should be checked when diagnosing and following up SLE patients with ascites. Furthermore, until now, there have been no reports on how the CA125 levels fluctuates in LUPLE. We hypothesize that LUPLE is more associated with pseudopseudo Meigs' syndrome than we thought, and that CA-125 may be useful in distinguishing LUPLE from PLE caused by other causes. In order to prove our hypothesis, it is considered necessary to accumulate more similar cases. In patients with pleural effusion, ascites and high CA 125 levels, it is important to consider the possibility that SLE with pseudo-pseudo Meigs' syndrome is the cause of symptoms in order to avoid excessive treatment such as diagnosing these patients as Meigs' syndrome or pseudoMeigs' syndrome and performing surgery.

Corticosteroids are effective for LUPLE and pseudo-pseudo Meigs' syndrome, and a good prognosis has been shown with a combined steroid and immunosuppressive therapy [2, 8, 9]. In treating pseudo-pseudo Meigs' syndrome, administering moderate-dose corticosteroids in case of an underlying tumour, Meigs' syndrome, and pseudo-Meigs' syndrome and then adding immunosuppressive agents are recommended [12]. In our patient, the combination of DEX and HCQ was effective, but whether DEX treatment alone would have been adequate was unclear. Hydroxychloroquine (HCQ) is effective for treating cutaneous lupus erythematosus and SLE symptoms, such as rashes, joint pain and fatigue [13]. According to the Japanese Guideline for the Management of SLE (2019), HCQ is recommended for the treatment of skin lesions, arthritis and renal lesions [14]. In addition, HCQ can prevent disease flare in SLE patients and improve survival rates. The European League against Rheumatism recommended in 2019 that all SLE patients receive HCQ at a dose not exceeding $5 \mathrm{mg} / \mathrm{kg}$ real body weight [15]. Several studies demonstrated the effectiveness of HCQ in Japanese patients, which permitted the reduction of the corticosteroid dose [16, 17]. HCQ is also effective in the treatment of LUPLE and pseudopseudo Meigs' syndrome, and is expected to be effective in reducing the dose of steroids.

In conclusion, LUPLE and pseudo-pseudo Meigs' syndrome occur in patients with SLE and are considered to be different disorders with similar clinical features that produce marked ascites. However, no reports have confirmed elevated CA125 levels with LUPLE or increased ${ }^{99 \mathrm{~m}} \mathrm{Tc}-\mathrm{HSA}$ activity with pseudo-pseudo Meigs' syndrome. There may be latent cases where LUPLE and pseudo-pseudo Meigs' syndrome overlap. Clinicians should consider both diseases when evaluating women with idiopathic pleural effusion or ascites. While there have been no reports of LUPLE histopathology, we have examined LUPLE's histopathology for the first time. Furthermore, it was suggested that HCQ may be useful in the treatment of patients with SLE who have atypical symptoms such as LUPLE and pseudo-pseudo Meigs' syndrome. 
Se prezintă cazul unei enteropatii exudative asociate lupusului eritematos sistemic cu sindrom psuedo-Meigs. Acestea reprezintă complicații foarte rare. Au o evoluție clinică similară cu dezvoltare de ascită și răspund la tratamentul corticoid. $\hat{I n}$ cazul de față a fost nevoie de adăugarea hidroxiclorochinei pentru tratamentul eficient. Am observat și o creștere a CA 125, precum și a activității 99mTc-HSA. Totodată, este prima caracterizare histopatologică a enetropatiei exudative la pacienții cu lupus. Până în acest moment nu a fost evaluată prezența ambelor entități la pacienți. Cazul prezentat arată posibilitatea asocierii celor două entități. Totodată, este posibil ca pacienții cu ascită și niveluri crescute ale CA125 să fie diagnosticați cu sindrom Meigs asociat cu tumori ovariene benigne sau maligne și pot suferi intervenții chirurgicale. Nu trebuie uitată asocierea dintre lupus și sindromul pseudo-Meigs ca o cauză de creștere a CA 125 în diagnosticul diferențial.

Correspondence to: Taro Horino, MD, PhD, Department of Endocrinology, Metabolism and Nephrology, Kochi Medical School, Kochi University, Kohasu, Oko-cho, Nankoku, Kochi 783-8505, Japan

Tel: +81-88-880-2343, Fax: +81-88-880-2344, E-mail: horinott@yahoo.co.jp

Conflict of interest disclosure: The author declares that there are not conflicts of interest.

\section{REFERENCES}

1. ARINGER M., COSTENBADER K., DAIKH D., BRINKS R., MOSCA M., RAMSEY-GOLDMAN R., et al. 2019 European League Against Rheumatism/American College of Rheumatology classification criteria for systemic lupus erythematosus. Ann Rheum Dis. 2019;78(9):1151-9.

2. AL-MOGAIREN SM. Lupus protein-losing enteropathy (LUPLE): a systematic review. Rheumatol Int. 2011;31(8):995-1001.

3. TIALMA WA. Ascites, pleural effusion, and CA 125 elevation in an SLE patient, either a Tjalma syndrome or, due to the migrated Filshie clips, a pseudo-Meigs syndrome. Gynecol Oncol. 2005;97(1):288-91.

4. HOCHBERG MC. Updating the American College of Rheumatology revised criteria for the classification of systemic lupus erythematosus. Arthritis Rheum. 1997;40(9):1725.

5. PETRI M., ORBAI AM., ALARCON GS., GORDON C., MERRILL JT., FORTIN PR., et al. Derivation and validation of the Systemic Lupus International Collaborating Clinics classification criteria for systemic lupus erythematosus. Arthritis Rheum. 2012;64(8):2677-86.

6. YOSHIDA M., MIYATA M., SAKA M., SASAJIMA T., SATO H., TAKIGUCHI J., et al. Protein-losing enteropathy exacerbated with the appearance of symptoms of systemic lupus erythematosus. Intern Med. 2001;40(5):449-53.

7. CHUNG U., OKA M., NAKAGAWA Y., NISHISHITA T., SEKINE N., TANAKA Y., et al. A patient with protein-losing enteropathy associated with systemic lupus erythematosus. Intern Med. 1992;31(4):521-4.

8. WERNER DE CASTRO GR., APPENZRLLER S., BERTOLO MB., COSTALLAT LT. Protein-losing enteropathy associated with systemic lupus erythematosus: response to cyclophosphamide. Rheumatol Int. 2005;25(2):135-8.

9. TANSIR G., KUMAR P., PIUS A., SUNNY SK., SONEJA M. Pseudo-pseudo Meigs' syndrome: a rare presentation of systemic lupus erythematosus. Reumatismo. 2019;71(2):108-12.

10. YANG Z., LIANG Y., LI C., ZHONG R. Serum CA125 elevation is independently associated with serositis in SLE patients. Clin Exp Rheumatol. 2012;30(1):93-8.

11. ZEIMET AG., MARTH C., OFFNER FA., OBRIST P, UHL-STEIDL M., FEICHTINGER H. Human peritoneal mesothelial cells are more potent than ovarian cancer cells in producing tumor marker CA-125. Gynecol Oncol. 1996;62(3):384-9.

12. LI T, XIE QB. A case report of pseudo-pseudo Meigs' syndrome. Chin Med J (Engl). 2019;132(12):1497-8.

13. FAVA A, PETRI M. Systemic lupus erythematosus: diagnosis and clinical management. J Autoimmun. 2019;96:1-13.

14. Health and Labor Sciences Research Grant Subsidy for Intractable Disease Policy Research. Project, Research on autoimmune diseases, Japan college of Rheumatology. Guideline for the management of systemic lupus erythematosus 2019;2019:226-30 (in Japanese)

15. FANOURIAKIS A., KOSTOPOULOU M., ALUNNO A., ARINGER M., BAJEMA I., BOLETIS JN. 2019 update of the EULAR recommendations for the management of systemic lupus erythematosus. Ann Rheum Dis. 2019;78(6):736-45.

16. HANAOKA H., IIDA H., KIYOKAWA T., TAKAKUWA Y., KAWAHATA K. Hydroxychloroquine improves the disease activity and allows the reduction of the corticosteroid dose regardless of background treatment in Japanese patients with systemic lupus erythematosus. Intern Med. 2019;58(9):1257-62.

17. MIYAGAWA I., NAKANO K., NAKAYAMADA S., IWATA S., HANAMI K., FUKUYO S. Effectiveness and safety of hydroxychloroquine therapy with or without corticosteroid in patients with systemic lupus erythematosus. Int J Rheum Dis. 2019;22(3):434-42.

Received $26^{\text {th }}$ May 2021 